Article Type: Research Paper

\title{
Islamic Banks' Stability: Full-Fledged vs Islamic Windows
}

\author{
Arief Ichwanul Hasan ${ }^{1}$ and Tastaftiyan Risfandy ${ }^{2 *}$
}

\begin{abstract}
:
Research aims: This paper investigates whether Islamic windows have better stability than full-fledged Islamic banks.

Design/Methodology/Approach: A sample of 14 Islamic banks and 19 Islamic windows banks in Indonesia from 2013 to 2018 was used in this study. Both ordinary least squares and panel fixed effects were employed to examine the stability of both Islamic banks' types.

Research findings: Our empirical result suggested that full-fledged Islamic banks were less stable than their Islamic windows counterparts. This result remained consistent after running the model with different estimators and conducting various robustness tests.

Theoretical contribution/Originality: Our result implies that Islamic windows could enjoy their market position to maintain stability without converting themselves into full-fledged Islamic banks because the Islamic banking market's current condition is highly competitive.

Practitioner/Policy implication: Our empirical evidence supports the Indonesian governments' policy in converting Islamic windows banks into full-fledged Islamic banks if the market's competitive condition is well monitored by the regulators.

Research limitation/Implication: This research result is limited only to the Indonesian setting and can be different if the analysis is taken using a sample from other countries.

Keywords: Islamic Banks; Full-Fledged; Islamic Windows; Stability, Indonesia
\end{abstract}

AFFILIATION:

${ }^{1,2}$ Department of Management, Faculty of Economics and Business, Universitas Sebelas Maret, Central Java, Indonesia

\section{*CORRESPONDENCE:}

tastaftiyan.risfandy@staff.uns.ac.id

THIS ARTICLE IS AVAILABLE IN:

http://journal.umy.ac.id/index.php/ai

DOI: 10.18196/jai.v22i1.10287

\section{CITATION:}

Hasan, A.I. \& Risfandy, T. (2021). Islamic banks' stability: Full-fledged vs Islamic windows. Journal of Accounting and Investment, 22(1), 192-205.

\section{ARTICLE HISTORY}

\section{Received:}

16 Nov 2020

Revised:

07 Jan 2021

12 Jan 2021

Accepted:

14 Jan 2021

\section{Introduction}

The global economy dynamics show a great impact in many sectors at the domestic level, including the banking industry. As a result, in Indonesia, the banking industry is demanded to make breakthroughs to improve its performance in several aspects of the business. This breakthrough is in the form of the banks' efforts to have a new mindset in looking at existing problems and opportunities from different perspectives. One of the options utilized by banking institutions in Indonesia is opening an Islamic business unit within conventional banks' umbrella, or widely known as Islamic window banks. The Islamic windows are considered an opportunity for conventional banks to expand their business and market share, considering that approximately $87 \%$ of Indonesia's population is Muslim (Pew Research Center, 2009). 


\author{
Hasan \& Risfandy \\ Islamic Banks' Stability: Full-Fledged vs Islamic Windows
}

The financial system's efficiency can be measured in terms of the efficiency achieved in mobilizing savings from surplus savings units and allocating funds to deficit savings units in the economy (Obaidullah, 2006). With the presence of Islamic banks and Islamic window banks, all banks' elements are expected to contribute in a more precise and targeted manner to improve business and economic growth. Islamic banks have the potential to develop in the future and experience faster growth than conventional banking after the 2008 crisis. In terms of performance, the difference in conventional banks' efficiency compared to Islamic banks is insignificant (Ismail, Shabri Abd. Majid, \& Rahim, 2013).

The phenomenon currently being faced by Islamic banking is the difficulty in penetrating the conventional banks' market share. Bank Indonesia has long been targeting a market share of $5 \%$ of total national banking assets, which implements the vision for Indonesian Islamic banking development. This target was only achieved after more than five years of being determined, based on statistical data. The market share of Indonesian Islamic banking until 2018 reached around 5.7 percent, and it was about five times lower than Malaysia (Rofi'ah, 2017).

Through Regulation No.11/10/PBI/2009, Bank Indonesia requires the conventional bank to spin-off the Islamic window banks owned if the portion of Islamic window banks' assets has reached $50 \%$ of its parent. Conventional banks are required to separate the Islamic business unit by 2023 or 15 years after enacting Law Number 21 of 2008 concerning Islamic banking. This separation has the aim to maximize the implementation of Islamic banking principle intervention from the parent. Moreover, the spin-off is intended to make Islamic commercial banks more flexible in making decisions and compete with their conventional peers to contribute more to the national economy (Abdul-Majid, Saal, \& Battisti, 2011a; Rongiyati, 2015).

According to the Otoritas Jasa Keuangan (OJK/Indonesia Financial Services Authority) statistics, in 2019, there were 14 Islamic banks and 19 Islamic window banks in Indonesia. In 2016, Islamic banks' market share only constituted $5.13 \%$, meaning that Indonesian banking can fulfill the $5 \%$ after 18 years of the law. According to the OJK, this condition is not in line with the government's vision of realizing a growing, sustainable, and equitable Islamic financial services industry that can contribute to the national economy and financial system stability towards Indonesia's realization as the world's center for Islamic finance.

Although many studies have compared Islamic banks and conventional banks' performance, few studies have compared the performance of full-fledged Islamic banks and Islamic windows. To the best of our knowledge, several previous studies, such as Abedifar, Molyneux, and Tarazi (2013), Alraheb and Tarazi (2018), and Ibrahim and Rizvi (2017), only compared the risk and stability of Islamic banks against conventional banks. Meanwhile, the other studies, such as Aik and Tan (2012); Ismail et al. (2013), Kamaruddin, Safa, and Mohd (2008), Mobarek and Kalonov (2014) and Salami and Adeyemi (2015), have studied differences in the performance of Islamic commercial banks and Islamic business units; they only focused on the efficiency, and all of them 


\author{
Hasan \& Risfandy \\ Islamic Banks' Stability: Full-Fledged vs Islamic Windows
}

used Malaysian setting. Therefore, this study investigates the stability of Islamic commercial banks and Islamic business units in Indonesia to determine whether Islamic units within conventional banks (Islamic windows) have better stability than full-fledged Islamic banks or vice versa.

Using a dataset of 14 full-fledged Islamic banks and 19 Islamic windows banks in Indonesia from 2013 to 2018, it was found that the full-fledged Islamic banks were less stable than Islamic ones. This result signals that the Islamic banking market is highly competitive, as suggested by some studies (Meslier, Risfandy, \& Tarazi, 2017; Risfandy, Tarazi, \& Trinugroho, 2020). This result enriches the literature in Islamic banks, particularly in comparing Islamic banks and Islamic windows, showing that the latter has better stability than the former. Our result suggested that Islamic windows could enjoy their market positions without converting themselves into full-fledged Islamic banks because the current Islamic banking market condition, especially in Indonesia, is highly competitive. Nevertheless, this result does not indicate that full-fledged Islamic banks are not a good option for the Islamic banking market. The conversion of Islamic windows into full-fledged Islamic banks can be an option for the Indonesian banking market if only the regulator maintains the Islamic banking market competitive condition.

The remainder of this paper is as follows. Section two provides a review of related literature. Section three highlights the methodology. Section four presents the empirical results. Section five concludes the research.

\title{
Literature Review
}

\section{Islamic Banks' Business Model}

Islamic banks are specifically characterized by the prohibition of collecting or paying interest at a predetermined rate (Obaidullah, 2006). The principles of Islamic banking transactions are regulated by the Figh Al-Muamelat, which only allows profit sharing (PLS) and non-profit sharing agreements (Abedifar et al., 2013). Therefore, Islamic banks use production sharing agreements, buy and resell the required goods or services with an agreed margin, and collect fees for services provided under the contract to earn income (Čihák \& Hesse, 2010).

Profit-sharing agreements (PLS), a financing method such as mudarabah and musharakah, make Islamic banks face specific risks related to this financing (Ashraf, Rizwan, \& L'Huillier, 2016). In a contract like this, the bank is quite dependent on the borrower, the bank's relationship with the customer is purely a business partner, and therefore, the bank cannot require collateral to cover possible losses from this funding (Abedifar et al., 2013; Hassan, Khan, \& Paltrinieri, 2019). Besides, the possibility of moral hazard, unbalanced information, limited access to financial records, and the obligation to bear part of the loss (musharakah) or the whole (mudarabah) lead to an increase in Islamic bank credit risk (Abedifar et al., 2013; Kabir, Worthington, \& Gupta, 2015). 


\author{
Hasan \& Risfandy \\ Islamic Banks' Stability: Full-Fledged vs Islamic Windows
}

On the one hand, Islamic banking seems to benefit from several factors that reduce credit risk. A profit-sharing system (PLS) allows Islamic banks to share losses with depositors (How, Karim, \& Verhoeven, 2005). Islamic bank operations based on Islamic principles attract customers with a high religiosity level, who have high market discipline and loyalty and do not default (Abedifar et al., 2013; Baele, Farooq, \& Ongena, 2014). However, on the other hand, the limitation of ways to manage risk causes Islamic banks to face higher credit risk. Among them, Kabir et al. (2015) suggested a prohibition of using debt-based instruments to limit credit risk. Then, speculative methods, such as swaps, futures, and options, are prohibited, and collateral is not permitted (Abedifar et al., 2013; Hassan et al., 2019). Also, there is an obligation to bear all losses, causing Islamic banks' credit risk to be higher than commercial banks (Bourkhis \& Nabi, 2013; Sundararajan \& Errico, 2002). High credit risk requires Islamic banks to have more effective risk management (Sundararajan \& Errico, 2002).

\title{
Islamic Windows Banks
}

The Islamic window banks began when the Central Bank of Malaysia or Bank Negara Malaysia (BNM) introduced the "Interest-Free Banking Scheme" in 1993, which allows conventional banks to offer Islamic banking products to customers (Aik \& Tan, 2012). This scheme has proven successful in Malaysia and has brought Islamic banking assets to RM94.6 billion, which was 8\% of Malaysia's total banking assets in 2012 (Abdul-Majid, Saal, \& Battisti, 2011b). In Indonesia, the Islamic windows were established after the issuance of Law no. 10 of 1998. With a more explicit legal basis, several conventional banks have established Islamic window banks because commercial banks can diversify their revenue by operating in Islamic, conventional, or both ways (Umam, 2010). Conventional banks, such as Bank Mega, Bank Mandiri, Bank BNI, Bank BRI, and others, started Islamic windows (namely, Bank Mega Syariah, Bank Mandiri Syariah, Bank BNI Syariah, and Bank BRI Syariah) entering the Islamic banking market that, at that time, only Bank Muamalat Indonesia acted as a single player.

Because the Islamic window banks' operation uses assets and resources from its conventional parent bank, Islamic window banks can have better efficiency than fullfledged Islamic banks (Salami \& Adeyemi, 2015). Conventional banks have a separate Islamic Banking division to run Islamic window banks business (Abdul-Majid et al., 2011b). Islamic window banks' business activity reports and Islamic banking portfolios are included in the conventional parent's main financial report. Conventional banks must form committees containing Islamic banking experts to determine the products' suitability offered with Islamic principles, and it must periodically be reported (AbdulMajid et al., 2011b).

\section{Islamic Banks' Stability}

There has been extensive research comparing the stability of Islamic banks and commercial banks. These studies used accounting parameters, such as Non-Performing Loans (NPL), Loan-loss Reserve, and Z-Score. Abedifar et al. (2013) examined the differences in risk faced by Islamic banks, conventional banks with Islamic window 


\author{
Hasan \& Risfandy \\ Islamic Banks' Stability: Full-Fledged vs Islamic Windows
}

banks, and conventional banks using the Z-score as a proxy for measuring insolvency loan-loss reserve as a proxy for credit risk. Using data from 24 countries for ten years between 1999 and 2009, they revealed that small Islamic banks' credit risk was lower in Muslim-majority countries than conventional banks. Besides, from the side of bankruptcy risk, small Islamic banks appeared more stable. Other researchers like Faye, Triki, and Kangoye (2013) observed the efficiency, business orientation, and asset quality of Islamic banking and commercial banks in 45 African countries from 2005 to 2010. The results of the study revealed that Islamic banks were more stable with higher Z-scores and lower NPLS.

In contrast, Beck, Demirgüç-Kunt, and Merrouche (2013) examined the stability, efficiency, and orientation of Islamic and general banking businesses in 22 Asian and European countries in 2005-2009. The empirical results showed that the asset quality seen from the NPL of Islamic banks had a smaller NPL value, meaning that Islamic banks' quality was better. Likewise, with stability, a higher Z-Score of Islamic banks signified conventional banks were more unstable than Islamic banks. Based on data from the Middle East and North Africa (MENA) and Southeast Asia countries in 2000-2008, Rajhi and Hassairi (2012) found a smaller Z-Score on large conventional banks, indicating that large conventional banks tended to be less stable than Islamic banks, and small Islamic banks were less stable than small conventional banks.

\title{
Too Big to Fail
}

Prior to 2008, banks in many countries worldwide competed to increase their size to boost profits using cheap international sources of funds. It resulted in a bank's scale, becoming very large and even exceeding the country's GDP where the bank was located (Demirgüç-Kunt \& Huizinga, 2013). However, after the 2008 crisis, the United States and the European Union governments issued regulations to curb the growth rate of bank growth by increasing the amount of bank capital and liquidity and tightening provisions on risky activities (Beccalli, Anolli, \& Borello, 2015).

Many reasons drive a bank to grow to be very large, one of which is to get the status too big to fail (TBTF). It is done to reap the benefits of cheap funding from financial security funds related to the bank size increase (Demirgüç-Kunt \& Huizinga, 2013). Too big to fail, or TBTF as it is called, began to get into the hot air in 1984, when the 7th largest US bank, Continental Illinois, was about to crash. The US deposit insurance agency (FDIC) immediately took action and provided unlimited guarantees for all public funds in the bank. As a bank in the top 10 in the US, the fall of Continental Illinois would have a devastating effect on US financial stability (Völz \& Wedow, 2011).

A bank pursuing TBTF status will use existing resources to continue to grow beyond the optimal size (Völz \& Wedow, 2011). This finding is supported by some studies (Kane, 2000; Penas \& Unal, 2004). The merger of several banks that will give birth to a TBTF bank will increase the shareholders' wealth (Kane, 2000) and increase debt holders' profits (Penas \& Unal, 2004). The banking industry that continues to improve will make banks bigger to disrupt economic stability if they go bankrupt, and the bank becomes 


\author{
Hasan \& Risfandy \\ Islamic Banks' Stability: Full-Fledged vs Islamic Windows
}

too big to be rescued (Völz \& Wedow, 2011). Banks that are large and important in financial stability can increase value by downsizing or separating, especially in weak economies (Demirgüç-Kunt \& Huizinga, 2013).

\title{
Research Method
}

This paper utilized a dataset of 14 full-fledged Islamic banks and 19 Islamic windows banks in Indonesia from 2013 to 2018. The data were obtained from the banks' annual reports and the website of the OJK. In order to avoid the presence of outliers in the data that could cause bias regression results, extreme values were minorized in the data at $1 \%$ and $99 \%$ percentiles. The final sample reached 110 observations.

The stability measures used in this study were the z-Score and Non-Performing Loans (NPL), which have been extensively employed in the literature (Abedifar et al., 2013; Beck et al., 2013; Čihák \& Hesse, 2010; Hassan et al., 2019; Ibrahim \& Rizvi, 2017; Kabir et al., 2015). While the NPL could be a proxy to measure asset quality, it could also measure bank stability along with the z-score (Risfandy et al., 2020). The ability of the zscore to identify risks, both across periods and during the crisis (2008-2011), is at least as good as the CAMELS, but the Z-Score requires fewer data, and the Z-score proves to be more effective when the bank business may be more sophisticated as is the case for large and commercial banks (Chiaramonte, Croci, \& Poli, 2015). The z-score is calculated as follows: Z-score $=(R O A+C A R) / \sigma(R O A)$. ROA is the rate of return on assets; CAR is the ratio of capital to assets; whereas $\sigma(R O A)$ is the standard deviation of the rate of return on assets (ROA). The lower the Z-score, the greater the possibility for a bank to go bankrupt, and conversely, a high Z-score indicates that the bank is more stable (Abedifar et al., 2013).

This study's first independent variable, which is the main variable of interest, was Islamic windows banks (IW). It is a dummy variable that takes a value equal to one if it is an Islamic window and zero if it is a full-fledged Islamic bank. Therefore, IW's significant coefficient suggests a significant difference between full-fledged and Islamic windows' stability. In this paper, several control variables were also employed. First, solvency risk was considered one of the determinants of bank stability, following Risfandy et al. (2020) and Ibrahim, Salim, Abojeib, and Yeap (2019). Higher solvency is associated with higher stability. Second, the cost to income ratio (CIR) was used to proxy efficiency. It was calculated by dividing the total operating cost by total income. A higher ratio indicates lower efficiency. This proxy has been used previously, such as Abedifar et al. (2013) and Kwan and Eisenbeis (1997). They revealed that the cost inefficiency positively influenced bank stability in terms of credit risk. Third, NIM was utilized to proxy profitability. As suggested by prior empirical studies, profitability is an essential determinant of bank stability (Beck et al., 2013; Čihák \& Hesse, 2010; Risfandy et al., 2020). Credit risk will decrease if profitability increases (Kabir et al., 2015). Other studies suggested that stability was negatively related to the level of probability (Worrell, Maechler, \& Mitra, 2007). Fourth, Financing Deposit Ratio (FDR) was introduced. This variable assesses banks' ability to convert deposits into profitable loans with higher 


\author{
Hasan \& Risfandy \\ Islamic Banks' Stability: Full-Fledged vs Islamic Windows
}

ratios indicate a higher level of intermediation (Alraheb, Nicolas, \& Tarazi, 2019). The ratio values of more than one show that some of the lendings come from other sources than savings, leading to instability (Beck, Demirgüç-Kunt, \& Levine, 2010). Fifth, LogTA was employed as the last control variable in this study. This variable is regarded as crucial to differ full-fledged Islamic banks and Islamic windows because Islamic windows bank has a relatively smaller size when compared to Islamic banks (Abedifar et al., 2013; Bourkhis \& Nabi, 2013; Čihák \& Hesse, 2010). Larger banks will be easier and have a better chance of diversifying risk through their ability, experience, and their network of branches. The size of the bank, therefore, is predicted to have a positive relationship with stability.

To investigate whether Islamic windows' stability differs from their full-fledged counterparts, an econometric specification was formed as follows.

$$
\log Z_{i t}=\alpha_{0}+\beta_{1} I W_{i t}+\beta_{2} C I R_{i t}+\beta_{3} R O E+\beta_{4} F D R+\beta_{5} L o g T A_{i t}+\varepsilon
$$

Where $i$ and $t$ refer to bank and time index, respectively. The equation (1) is estimated using the ordinary least squares (OLS) and panel random effect (RE). The choice of using RE for panel data analysis is because the main variable of interest of IW (Islamic Windows) is a rarely changing variable or relatively time-invariant variable. The use of fixed effects, in this case, is inappropriate (Arifin, Hasan, \& Kabir, 2020; Doumpos, Hasan, \& Pasiouras, 2017). The coefficient of $\beta$ _1become the main focus; if the $\beta \_1$ significant, it implies that Islamic windows' stability differs from their full-fledged counterparts.

\title{
Result and Discussion
}

\section{Descriptive Statistics}

The descriptive statistics of the variables are presented in Table 1. The mean of each variable is consistent with most of the previous studies. Indonesian Islamic banks had a high capital-assets-ratio with a mean value of $23 \%$, suggesting that Islamic banks were high-capitalized compared to the conventional banks, as reported by some studies (Beck et al., 2013; Meslier et al., 2017, among others). Islamic banks also had considerably good efficiency, as can be seen from the average value of cost to income ratio $(C I R) 89 \%$. The average value of net interest margins was $6 \%$, which was lower than Indonesian Islamic rural banks (Trinugroho, Risfandy, \& Ariefianto, 2018). From the variable FDR, it could be seen that Islamic banks in Indonesia, on average, had allocated $93 \%$ of their deposits for lending. It is also interesting to see that in the rightmost column, Islamic banks only significantly differed from Islamic windows in terms of efficiency (CIR) and profitability (NIM). 
Hasan \& Risfandy

Islamic Banks' Stability: Full-Fledged vs Islamic Windows

Table 1 Descriptive statistics and variables explanation $(N=96)$

\begin{tabular}{|c|c|c|c|c|c|c|}
\hline Variable & Explanation & Mean & Std. Dev. & Min & Max & Diff. (t-stat.) \\
\hline $\log Z_{i t}$ & $\begin{array}{l}\text { Logarithm of the } z \text {-score to } \\
\text { proxy stability. The } z \text {-score is } \\
\text { computed as } \\
\left(\mathrm{ROA}_{\mathrm{it}}+\mathrm{CAR}_{\mathrm{it}}\right) / \mathrm{SDROA}\end{array}$ & 2.428 & 0.444 & 1.909 & 3.501 & -0.856 \\
\hline$I W_{i t}$ & $\begin{array}{l}\text { Islamic windows dummy } \\
\text { variable equals one if Islamic } \\
\text { windows }\end{array}$ & 0.115 & 0.320 & 0 & 1 & - \\
\hline$C A R_{i t}$ & $\begin{array}{l}\text { Capital-assets-ratio to proxy } \\
\text { solvency }\end{array}$ & 23.094 & 13.491 & 12.010 & 63.890 & 0.552 \\
\hline$C I R_{i t}$ & $\begin{array}{l}\text { Cost to income ratio to proxy } \\
\text { efficiency }\end{array}$ & 89.373 & 15.796 & 51.680 & 134.630 & $4.596 * * *$ \\
\hline$N I M_{i t}$ & $\begin{array}{l}\text { Net interest margin to proxy } \\
\text { profitability }\end{array}$ & 6.202 & 2.362 & 2.440 & 11.990 & $-3.241 * * *$ \\
\hline$F D R_{i t}$ & Funding to deposit ratio & 93.909 & 19.401 & 63.600 & 157.770 & 0.018 \\
\hline $\operatorname{LogTA}_{i t}$ & $\begin{array}{l}\text { Logarithm of total assets to } \\
\text { proxy size }\end{array}$ & 16.006 & 1.208 & 13.372 & 17.837 & -0.031 \\
\hline
\end{tabular}

Table 2 Correlation matrix and variance inflation factors (VIF)

\begin{tabular}{|c|c|c|c|c|c|c|c|}
\hline & IW & CAR & $C I R$ & NIM & FDR & $\log T A$ & VIF \\
\hline$I W$ & 1 & & & & & & 1.34 \\
\hline$C A R$ & -0.057 & 1 & & & & & 2.48 \\
\hline$C I R$ & -0.428 & -0.131 & 1 & & & & 1.35 \\
\hline NIM & 0.317 & 0.106 & -0.291 & 1 & & & 1.17 \\
\hline$F D R$ & -0.002 & 0.652 & -0.152 & 0.134 & 1 & & 1.77 \\
\hline $\log T A$ & 0.003 & -0.643 & -0.034 & -0.040 & -0.448 & 1 & 1.78 \\
\hline
\end{tabular}

The correlation matrix and variance-inflation-factors (VIF) is provided in Table 2. It could be seen that there were no multicollinearity problems as all of the variable's correlation coefficients were less than 0.7 , and the highest VIF was 2.4 .

\section{Regression Results}

The regression result of equation (1) is shown in Table 3. It showed that the main variable of $I W$ was significant and positively affected $\log Z$. It implied that the stability of full-fledged Islamic banks was significantly different from Islamic windows. More surprisingly, the positive sign suggested that Islamic windows' stability was better than the full-fledged counterparts. This empirical finding may contradict the Indonesian government's spirit issuing regulation No.11/10/PBI/2009, namely to motivate each Islamic windows bank to convert themselves into full-fledged Islamic banks when they reach a specific size. There is a possible reason behind this finding. The literature has been widely discussed that the Islamic banking market's competitive condition has been considerably high (Meslier et al., 2017; Risfandy et al., 2020). Islamic banks have to compete with: (1) the other Islamic banks and (2) conventional banks. If an Islamic windows bank decides to convert itself into a full-fledged Islamic bank, they have to compete with two other types of banks in the very competitive market, and this is not an easy task to do. Although they are usually owned by their conventional parents after the conversion, the condition will be relatively different because they do not have direct 


\section{Hasan \& Risfandy \\ Islamic Banks' Stability: Full-Fledged vs Islamic Windows}

financial "backup" as previously. Indeed, full-fledged Islamic banks are more independent than Islamic windows, but if it could not fulfill Islamic windows' trade-off, converting them into full-fledged is meaningless. Therefore, this finding did not necessarily suggest Islamic windows not to convert into full-fledged Islamic banks. The Islamic windows could still have a plan to convert into Islamic banks if the government (regulator) maintains the competitive condition, especially in the Islamic banking market.

This finding is also consistent with the recent works by Trinugroho, Santoso, Irawanto, and Pamungkas (2020). Using the difference-in-difference (DiD) method, they found evidence that both performance and efficiency declined following a spin-off (the separation of Islamic windows from its parents to be a full-fledged Islamic bank). The new full-fledged Islamic banks had an inferior performance at least for four years after the conversion. Trinugroho et al. (2020) argued that although full-fledged Islamic banks' capital would increase after the spin-off, they could not reach similar economies of scale as conventional banks. It was because their size was relatively small compared to existing conventional banks in the market. The spin-off also has several disadvantages, such as potential loss of revenue diversification and disruption in the business and operations (Prasetyo, Luxianto, Baskoro, Adawiyah, \& Putri 2019).

Table 3 Main results

\begin{tabular}{|c|c|c|}
\hline & OLS & RE \\
\hline & (1) & (2) \\
\hline \multirow[t]{2}{*}{$I W$} & $0.101^{* * *}$ & $0.103^{* * *}$ \\
\hline & (3.84) & (3.68) \\
\hline \multirow[t]{2}{*}{$C A R$} & $0.0315^{* * *}$ & $0.0315^{* * *}$ \\
\hline & (14.69) & (13.80) \\
\hline \multirow[t]{2}{*}{$C I R$} & $-0.00443^{* * *}$ & $-0.00410^{* * *}$ \\
\hline & $(-4.87)$ & $(-3.24)$ \\
\hline \multirow[t]{2}{*}{ NIM } & 0.00613 & 0.00341 \\
\hline & (1.44) & $(0.78)$ \\
\hline \multirow[t]{2}{*}{$F D R$} & $-0.00342^{* * *}$ & $-0.00306^{* * *}$ \\
\hline & $(-3.28)$ & $(-3.60)$ \\
\hline \multirow[t]{2}{*}{$\log T A$} & $-0.0486^{* * *}$ & $-0.0440^{* * *}$ \\
\hline & $(-4.80)$ & $(-3.30)$ \\
\hline \multirow[t]{2}{*}{ Constant } & $3.063^{* * *}$ & $2.948^{* * *}$ \\
\hline & $(14.41)$ & (10.79) \\
\hline N obs. & 96 & 96 \\
\hline $\mathrm{N}$ banks & 13 & 13 \\
\hline R-sq. & 0.56 & 0.57 \\
\hline \multicolumn{3}{|c|}{$\begin{array}{l}\text { Notes: Regression results based on equation (1) using ordinary least squares (column (1)) and } \\
\text { random effects estimator (column ( } 2 \text { )). The dependent variable is LogZ. Please see Table } 1 \text { for } \\
\text { the description of variables. Year fixed effects are included in all estimations. Robust t } \\
\text { statistics are in parentheses. } * * *, * * \text {, and } * \text { denotes significance in } 1 \%, 5 \% \text {, and } 105 \text { levels } \\
\text { respectively. }\end{array}$} \\
\hline
\end{tabular}

Regarding control variables, it was observed that $C A R$ had a positive association with LogZ. The banks with higher solvency were associated with higher stability. CIR 


\section{Hasan \& Risfandy \\ Islamic Banks' Stability: Full-Fledged vs Islamic Windows}

negatively impacted LogZ, implying that banks with lower stability (higher CIR) were better stable (higher LogZ). It was not found a significant coefficient for NIM, which implied that Islamic banks' stability was not affected by how they set their margins. FDR had a negative impact on LogZ, indicating that higher lending distributed by Islamic banks was associated with lower stability. It might be because, different from conventional banks with several funding sources (e.g., money market), Islamic banks have only depositors' funds. LogTA as a proxy of size showed a negative sign, signifying that a larger bank had a larger default probability. It is consistent with (Čihák \& Hesse, 2010) and the too-big-to-fail (TBTF) theory. Larger banks have a complex structure and operations that make them vulnerable to being the default.

\section{Robustness Checks}

To test our result's consistency, several robustness checks were conducted and presented the result in Table 4.

Table 4 Robustness checks

\begin{tabular}{|c|c|c|c|c|c|}
\hline & (1) & (2) & (3) & (4) & (5) \\
\hline \multirow[t]{2}{*}{ IW } & $0.119^{* * *}$ & $0.0865^{* * *}$ & $0.0843^{* * *}$ & $0.103^{* * *}$ & $0.264^{* * *}$ \\
\hline & (3.27) & (3.07) & (3.20) & $(2.82)$ & $(4.97)$ \\
\hline \multirow[t]{2}{*}{ CAR } & $0.0329^{* * *}$ & $0.0334^{* * *}$ & $0.0294^{* * *}$ & $0.0315^{* * *}$ & \\
\hline & (13.25) & (15.78) & (11.51) & (22.79) & \\
\hline \multirow[t]{2}{*}{$C I R$} & $-0.00271^{*}$ & $-0.00279^{*}$ & $-0.00366^{* * *}$ & $-0.00410^{* * *}$ & \\
\hline & $(-1.94)$ & $(-1.93)$ & $(-2.63)$ & $(-5.31)$ & \\
\hline \multirow[t]{2}{*}{ NIM } & -0.00128 & -0.00323 & -0.00155 & 0.00341 & \\
\hline & $(-0.24)$ & $(-0.73)$ & $(-0.35)$ & $(0.75)$ & \\
\hline \multirow[t]{2}{*}{ FDR } & $-0.00311^{* * *}$ & $-0.00256^{* * *}$ & & $-0.00306^{* * *}$ & \\
\hline & $(-3.24)$ & $(-2.66)$ & & $(-4.30)$ & \\
\hline \multirow[t]{2}{*}{$\log T A$} & -0.0202 & & $-0.0373^{* *}$ & $-0.0440^{* * *}$ & \\
\hline & $(-1.20)$ & & $(-2.32)$ & $(-3.29)$ & \\
\hline \multirow[t]{2}{*}{ L.CAR } & & & & & $0.0274^{* * *}$ \\
\hline & & & & & (14.53) \\
\hline \multirow[t]{2}{*}{ L.CIR } & & & & & 0.00123 \\
\hline & & & & & $(0.45)$ \\
\hline \multirow[t]{2}{*}{ L.NIM } & & & & & $0.0292^{* * *}$ \\
\hline & & & & & (2.74) \\
\hline \multirow[t]{2}{*}{ L.FDR } & & & & & -0.00118 \\
\hline & & & & & $(-0.63)$ \\
\hline \multirow[t]{2}{*}{ L.LogTA } & & & & & -0.0258 \\
\hline & & & & & $(-0.98)$ \\
\hline \multirow[t]{2}{*}{ Constant } & $2.521^{* * *}$ & $2.110^{* * *}$ & $2.610^{* * *}$ & $2.948^{* * *}$ & $1.794^{* *}$ \\
\hline & (7.51) & $(12.72)$ & (8.17) & $(11.08)$ & $(2.56)$ \\
\hline N obs. & 96 & 96 & 96 & 96 & 84 \\
\hline $\mathrm{N}$ banks & 13 & 13 & 13 & 13 & 13 \\
\hline Year FE & No & Yes & Yes & Yes & Yes \\
\hline R-sq. & 0.46 & 0.56 & 0.56 & 0.66 & 0.72 \\
\hline $\begin{array}{l}\text { Notes: } \mathrm{Re} \\
\text { variable is } \\
* * *, * * \text {, a }\end{array}$ & $\begin{array}{l}\text { esults based } \\
\text { se see Table } \\
\text { es significanc }\end{array}$ & $\begin{array}{l}\text { equation (1) } \\
\text { the descripti } \\
\%, 5 \% \text {, and } 1\end{array}$ & $\begin{array}{l}\text { g a random- } \\
\text { variables. Ro } \\
\text { gels respectiv }\end{array}$ & $\begin{array}{l}\text { is estimator. } \\
\text { t-statistics are }\end{array}$ & $\begin{array}{l}\text { dependen } \\
\text { arentheses }\end{array}$ \\
\hline
\end{tabular}

First, year fixed effects were excluded from the estimation to see whether the sign of IW is affected by the year dummy. The result in column (1) showed that the IW remained 


\author{
Hasan \& Risfandy \\ Islamic Banks' Stability: Full-Fledged vs Islamic Windows
}

significant. Second, it was excluded LogTA because, from the correlation matrix in Table 2 , it had a considerably high correlation coefficient with CAR (0.643). However, after excluding LogTA from estimation, the result was still similar. Third, still related to the multicollinearity issue, FDR was excluded, which had a correlation coefficient of 0.652 with CAR. Again, the result was still similar, suggesting that this current model was free from multicollinearity issues, and the significance of IW was not driven by other variables in the model. Fourth, it was also tested whether the random effect estimators with robust standard errors were relevant. Therefore, equation (1) was re-estimated using non-robust standard errors, and the result in column (4) confirmed that the result remained unchanged. Last, bank fundamental variables in the equation's right-hand side were often associated with the endogeneity problem stems from the reverse-causality problem. Therefore, it was lagged all of the independent variables and obtained a similar result, as depicted in column (5).

\title{
Conclusion
}

This paper intends to answer whether the Islamic windows have better or lower stability than their full-fledged counterparts. It was empirically compared the stability of Islamic banks vs. Islamic windows banks using the regression approach. The ordinary least squares and panel random effects estimators were used in this study. Strong evidence was found that the stability of full-fledged Islamic banks was weaker than Islamic windows. Indonesian Islamic windows had better stability. This empirical result could be because Islamic windows are still directly supported by their parents from full-fledged Islamic banks independent in any aspect. Considering that the Islamic banking industry, including Indonesia, is highly competitive, enjoying becoming Islamic windows could be a safe option to remain in the market and maintain stability. However, the result does not mean that the Indonesian government's policy to increase Islamic banks' share by promoting full-fledged Islamic banks is wrong. Instead, the current empirical evidence suggests policymakers to monitor the competitive condition in the Indonesian banking market because, as suggested by many studies, in the Islamic banking industry, higher competition is empirically associated with lower banking stability (Albaity, Mallek, \& Noman, 2019; Kabir \& Worthington, 2017; Risfandy et al., 2020). The Indonesian government could have the policy to increase the number of full-fledged Islamic banks, but the competitive condition should be monitored.

The result obtained from this research might be limited only to the Indonesian context. Although a single country study offers a specific and unique result compared to multiple countries, no generalization can be made from a single country study. This study's analysis is also limited only in comparing the full-fledged vs. Islamic windows banks' stability. The further study still can examine the stability of two bank types by considering some other factors, e.g., age. Indeed, the newly converted full-fledged Islamic banks may have lower performance than the other Islamic windows in a similar market. The future examination can also be enlarged into more than one country because other countries also have Islamic windows operating in a similar market, as explained by Abedifar et al. (2013). 


\author{
Hasan \& Risfandy \\ Islamic Banks' Stability: Full-Fledged vs Islamic Windows
}

\title{
References
}

Abdul-Majid, M., Saal, D. S., \& Battisti, G. (2011a). Efficiency and total factor productivity change of Malaysian commercial banks. The Service Industries Journal, 31(13), $2117-$ 2143. https://doi.org/10.1080/02642069.2010.503882

Abdul-Majid, M., Saal, D. S., \& Battisti, G. (2011b). The impact of islamic banking on the cost efficiency and productivity change of Malaysian commercial banks. Applied Economics, 43(16), 2033-2054. https://doi.org/10.1080/00036840902984381

Abedifar, P., Molyneux, P., \& Tarazi, A. (2013). Risk in Islamic banking. Review of Finance, 17(6), 2035-2096. https://doi.org/10.1093/rof/rfs041

Aik, N.-C., \& Tan, K.-E. (2012). A study of cost and profit efficiency of the full-fledged Islamic banks and Islamic windows in Malaysia. SEGi Review, 5(1), 41-46.

Albaity, M., Mallek, R. S., \& Noman, A. H. M. (2019). Competition and bank stability in the MENA region: The moderating effect of Islamic versus conventional banks.

Emerging Markets Review, 38(February), 310-325. https://doi.org/10.1016/j.ememar.2019.01.003

Alraheb, T. H., \& Tarazi, A. (2018). Local versus international crises and bank stability: Does bank foreign expansion make a difference? Applied Economics, 50(10), 1138-1155. https://doi.org/10.1080/00036846.2017.1352081

Alraheb, T. H., Nicolas, C., \& Tarazi, A. (2019). Institutional environment and bank capital ratios. Journal of Financial Stability, 43, 1-24. https://doi.org/10.1016/i.jfs.2019.05.016

Arifin, T., Hasan, I., \& Kabir, R. (2020). Transactional and relational approaches to political connections and the cost of debt. Journal of Corporate Finance, 65(Desember), 20-40. https://doi.org/10.1016/i.jcorpfin.2020.101768

Ashraf, D., Rizwan, M. S., \& L'Huillier, B. (2016). A net stable funding ratio for Islamic banks and its impact on financial stability: An international investigation. Journal of Financial Stability, 25(July), 47-57. https://doi.org/10.1016/i.jfs.2016.06.010

Baele, L., Farooq, M., \& Ongena, S. (2014). Of religion and redemption: Evidence from default on Islamic loans. Journal of Banking \& Finance, 44, 141-159. https://doi.org/10.1016/j.jbankfin.2014.03.005

Beccalli, E., Anolli, M., \& Borello, G. (2015). Are European banks too big? Evidence on economies of scale. Journal of Banking \& Finance, 58, 232-246. https://doi.org/10.1016/j.jbankfin.2015.04.014

Beck, T., Demirgüç-Kunt, A., \& Levine, R. (2010). Financial institutions and markets across countries and over time: The updated financial development and structure database. The World Bank Economic Review, 24(1), 77-92. https://doi.org/10.1093/wber/lhp016

Beck, T., Demirgüç-Kunt, A., \& Merrouche, O. (2013). Islamic vs. conventional banking: Business model, efficiency and stability. Journal of Banking \& Finance, 37(2), 433-447. https://doi.org/10.1016/j.jbankfin.2012.09.016

Bourkhis, K., \& Nabi, M. S. (2013). Islamic and conventional banks' soundness during the 2007-2008 financial crisis. Review of Financial Economics, 22(2), 68-77. https://doi.org/10.1016/i.rfe.2013.01.001

Chiaramonte, L., Croci, E., \& Poli, F. (2015). Should we trust the Z-score? Evidence from the European Banking Industry. Global Finance Journal, 28, 111-131. https://doi.org/10.1016/i.gfi.2015.02.002

Čihák, M., \& Hesse, H. (2010). Islamic banks and financial stability: An empirical analysis. Journal of Financial Services Research, 38(2), 95-113. https://doi.org/10.1007/s10693$\underline{010-0089-0}$ 


\section{Hasan \& Risfandy \\ Islamic Banks' Stability: Full-Fledged vs Islamic Windows}

Demirgüç-Kunt, A., \& Huizinga, H. (2013). Are banks too big to fail or too big to save? International evidence from equity prices and CDS spreads. Journal of Banking and Finance, 37(3), 875-894. https://doi.org/10.1016/j.jbankfin.2012.10.010

Doumpos, M., Hasan, I., \& Pasiouras, F. (2017). Bank overall financial strength: Islamic versus conventional banks. Economic Modelling, 64(August), 513-523. https://doi.org/10.1016/i.econmod.2017.03.026

Faye, I., Triki, T., \& Kangoye, T. (2013). The Islamic finance promises: Evidence from Africa. Review of Development Finance, 3(3), 136-151. https://doi.org/10.1016/i.rdf.2013.08.003

Hassan, M. K., Khan, A., \& Paltrinieri, A. (2019). Liquidity risk, credit risk and stability in Islamic and conventional banks. Research in International Business and Finance, 48(September), 17-31. https://doi.org/10.1016/j.ribaf.2018.10.006

How, J. C. Y., Karim, M. A., \& Verhoeven, P. (2005). Islamic financing and bank risks: The case of Malaysia. Thunderbird International Business Review, 47(1), 75-94. https://doi.org/10.1002/tie.20041

Ibrahim, M. H., \& Rizvi, S. A. R. (2017). Do we need bigger Islamic banks? An assessment of bank stability. Journal of Multinational Financial Management, 1(1), 1-38. https://doi.org/10.1016/i.mulfin.2017.05.002

Ibrahim, M. H., Salim, K., Abojeib, M., \& Yeap, L. W. (2019). Structural changes, competition and bank stability in Malaysia's dual banking system. Economic Systems, 43(1), 111-129. https://doi.org/10.1016/j.ecosys.2018.09.001

Ismail, F., Shabri Abd. Majid, M., \& Rahim, R. A. (2013). Efficiency of Islamic and conventional banks in Malaysia. Journal of Financial Reporting and Accounting, 11(1), 92 107. https://doi.org/10.1108/jfra-03-2013-0011

Kabir, M. N., \& Worthington, A. C. (2017). The 'competition-stability/fragility' nexus: A comparative analysis of Islamic and conventional banks. International Review of Financial Analysis, 50, 111-128. https://doi.org/10.1016/i.irfa.2017.02.006

Kabir, M. N., Worthington, A., \& Gupta, R. (2015). Comparative credit risk in Islamic and conventional bank. Pacific Basin Finance Journal, 34, 327-353. https://doi.org/10.1016/i.pacfin.2015.06.001

Kamaruddin, B. H., Safa, M. S., \& Mohd, R. (2008). Assessing production efficiency of Islamic banks and conventional bank Islamic windows in Malaysia. International Journal of Business and Management Science, 1(1), 31-48. Retrieved from http://www.safaworld.org/ijbms/abs/Abstracts\%20v1n12008/IJBMS $\% 20 \mathrm{Vol} \% 20$ $1 \% 20 \mathrm{No}^{2} \% 201 \% 20 \mathrm{July} \% 2008$-abs $\% 202$.pdf

Kane, E. J. (2000). Incentives for banking megamergers: What motives might regulators infer from event-study evidence? Journal of Money, Credit and Banking, 32(2), 671-701. https://doi.org/10.2307/2601202

Kwan, S., Eisenbeis, R.A. (1997). Bank risk, capitalization, and operating efficiency. Journal of Financial Services Research, 12, 117-131. https://doi.org/10.1023/A:1007970618648

Meslier, C., Risfandy, T., \& Tarazi, A. (2017). Dual market competition and deposit rate setting in Islamic and conventional banks. Economic Modelling, 63(July), 318-333. https://doi.org/http://dx.doi.org/10.1016/j.econmod.2017.02.013

Mobarek, A., \& Kalonov, A. (2013). Comparative performance analysis between conventional and Islamic banks: empirical evidence from OIC countries. Applied Economics, 46(3), 253-270. https://doi.org/10.1080/00036846.2013.839863

Obaidullah, M. (2006). Islamic financial products. Asia-Pacific Business Series, 59-86. https://doi.org/10.1142/9789812773050_0005 


\section{Hasan \& Risfandy \\ Islamic Banks' Stability: Full-Fledged vs Islamic Windows}

Penas, M. F., \& Unal, H. (2004). Gains in bank mergers: Evidence from the bond markets. Journal of Financial Economics, 74(1), 149-179. https://doi.org/10.1016/i.jfineco.2003.05.004

Pew Research Center. (2009). Mapping the global muslim population. Pew Research Center Report. Retrieved from https://www.pewresearch.org/wpcontent/uploads/sites/7/2009/10/Muslimpopulation.pdf

Prasetyo, M. B., Luxianto, R., Baskoro, R.A., Adawiyah, W., \& Putri, N.I.S. (2019). The role of capital on Islamic bank spin-offs in Indonesia. The South East Asian Journal of Management, 13(2), 119-139. https://doi.org/10.21002/seam.v13i2.11179

Rajhi, W., \& Hassairi, S. A. (2012). Islamic banks and financial stability: A comparative empirical analysis between MENA and Southeast Asian countries. SSRN Electronic Journal, 37, 149-177. https://doi.org/10.2139/ssrn.2010126

Risfandy, T., Tarazi, A., \& Trinugroho, I. (2020). Competition in dual markets: Implications for banking system stability. Global Finance Journal, (December). https://doi.org/10.1016/j.gfi.2020.100579

Rofi'ah, N. (2017). Analisis deskriptif perkembangan perbankan syariah di Asia Tenggara (2004-2016). The Journal of Taubidinomics, 1(2), 105-123.

Rongiyati, S. (2015). Pengembangan perbankan syariah melalui pelaksanaan kewajiban pemisahan unit usaha syariah. Negara Hukum, 6(1), 65-78. Retrieved from https://jurnal.dpr.go.id/index.php/hukum/article/view/247

Salami, O. L., \& Adeyemi, A. A. (2015). Malaysian islamic banks' efficiency: An intra-bank comparative analysis of islamic windows and full-fledged subsidiaries. International Journal of Business and Society, 16(1), 19-38. https://doi.org/10.33736/ijbs.551.2015

Sundararajan, V., \& Errico, L. (2002). Islamic financial institutions and products in the global financial system: Key issues in risk management and challenges ahead. Islamic Finance, 52-84. https://doi.org/10.4135/9788132107675.n3

Trinugroho, I., Risfandy, T., \& Ariefianto, M. D. (2018). Competition, diversification, and bank margins: Evidence from Indonesian Islamic rural banks. Borsa Istanbul Review, 18(4), 349-358. https://doi.org/10.1016/j.bir.2018.07.006

Trinugroho, I., Santoso, W., Irawanto, R., \& Pamungkas, P. (2020). Is spin-off policy an effective way to improve performance of Islamic banks? Evidence from Indonesia. Research in International Business and Finance, 56(October), 101-120. https://doi.org/10.1016/j.ribaf.2020.101352

Umam, K. (2010). Peningkatan ketaatan syariah melalui pemisahan (spin-off) unit usaha syariah bank umum konvensional. Mimbar Hukum, 22(3), 607-624. Retrieved from https://jurnal.ugm.ac.id/imh/article/view/16239

Völz, M., \& Wedow, M. (2011). Market discipline and too-big-to-fail in the CDS market: Does banks' size reduce market discipline? Journal of Empirical Finance, 18(2), 195210. https://doi.org/10.1016/i.jempfin.2011.01.001

Worrell, D., Maechler, A. M., \& Mitra, S. (2007). Decomposing Financial Risks and Vulnerabilities in Eastern Europe. IMF Working Papers, 7(248), 1-20. https://doi.org/10.5089/9781451868111.001 